\title{
An Exploration of Dynamic Relationships between Macroeconomic Variables and Stock Prices in Korea Revisited*
}

\author{
Jung Wan LEE ${ }^{1}$, Tantatape BRAHMASRENE ${ }^{2}$
}

Received: February 25, 2020 Revised: May 31, 2020 Accepted: September 04, 2020

\begin{abstract}
The paper revisits the author's previous paper to examine short-run and long-run dynamic relationships between macroeconomic variables and stock prices in Korea. The data is updated to the period for which monthly data are available from January 1986 to June 2018 (390 observations) retrieved from the Bank of Korea. The results of Johansen cointegration test indicate that at least one cointegrating equation exists, confirming there is a long-run equilibrium relationship between macroeconomic variables and stock prices in Korea. The results of vector error correction estimates confirm that: 1) the coefficient of the error correction term is significant with a negative sign, which is, a long-run dynamic relationship is observed between macroeconomic variables and stock prices; 2) for short-run dynamics, the nominal exchange rate of the Korean won per the US dollar is positively related to stock prices, while interest rates are negatively related to stock prices in the short-run; 3 ) the coefficient of global financial crises is insignificant, that is, the changes of stock prices are determined largely by their own dynamics in the model. The results suggest only that the global financial crises neither cause instability in the cointegrating vector, nor affect significant changes in the endogenous variables in the model.
\end{abstract}

Keywords: Stock Prices, Macroeconomic Variables, Global Financial Crisis, Causality, Korea

JEL Classification Code: G15, F31, E44, F37, G01

\section{Introduction}

Perhaps the two theories about the dynamic relationship between macroeconomic variables such as exchange rates

\section{*Acknowledgements:}

The paper, "An Exploration of Dynamical Relationships between Macroeconomic Variables and Stock Prices in Korea", has been published initially on the Journal of Asian Finance, Economics and Business, volume 5, issue 3, pp 7-17, on August 30, 2018. This paper is a substantially revised and corrected version, especially the results of cointegration tests and vector error correction estimates, i.e., long-run and short-run dynamics. The authors greatly appreciate editors and reviewers for their valuable comments, interest in and support for this research.

${ }^{1}$ First Author and Corresponding Author. School of International Economics and Trade, Anhui University of Finance and Economics (AUFE), China [Postal Address: 962 Caoshan Road, Bengbu City, Anhui Province, 233030, China] Email: jungwan.lee@aufe.edu.cn

${ }^{2}$ Professor of Finance \& International Business, College of Business, Purdue University Northwest, Indiana, United States.

Email: tapeb@pnw.edu

(C) Copyright: The Author(s)

This is an Open Access article distributed under the terms of the Creative Commons Attribution Non-Commercial License (https://creativecommons.org/licenses/by-nc/4.0/) which permits unrestricted non-commercial use, distribution, and reproduction in any medium, provided the unrestricted non-commercial use,
original work is properly cited. and stock prices are the traditional approach and the portfolio approach. Although these approaches have long been discussed, no consensus has been reached. The traditional approach claims that depreciation of the local currency makes local firms more competitive, leading to an increase in their exports and consequently higher stock prices. This implies a positive correlation between macroeconomic variables, exchange rates and stock prices. It also suggests that the fluctuation of exchange rates leads to the changes in stock prices. Conversely, the portfolio approach argues that an increase in stock prices induces investors to demand more domestic assets and thereby causes an appreciation in the local currency. Thus, changes in stock prices are inversely related to exchange rates.

Stock prices are generally interpreted as representing the present values of future cash flows of firms, reacting to exchange rate changes, and forming the link among future income, interest rates, current investment and consumption decisions (Zhao, 2010). In the floating exchange rate system, the exchange rate is essentially determined by a country's current account balance or trade balance. As a result, exchange rate fluctuations affect to some extent international competitiveness and trade balance. Consequently, it affects 
real income and stock prices, especially the stock price of export-oriented enterprises.

Two models explain the relationship between macroeconomic variables and stock prices. The flow-oriented model (Dornbusch \& Fisher, 1980) claims a positive linkage between selected macroeconomic variables and stock prices. Local currency depreciation leads to greater competitiveness of local firms given that their exports will be cheaper in international trade. Higher exports will increase the domestic income and, since the firms' stock prices are evaluated as the present value of the firms' future cash flows, they will also increase.

The stock-oriented model (Branson, Halttunen, \& Masson, 1977) of exchange rates asserts that the exchange rate serves to equalize the supply and demand for assets such as stocks and bonds. This model determines the exchange rate dynamics by giving the capital account a pivotal role. Since the values of financial assets are determined by the present values of their future cash flows, expectations of relative currency values play a considerable role in the price movements of the financial assets. Therefore, stock prices may affect, or be affected by, exchange rate dynamics (Zhao, 2010). As a result, if selected macroeconomic variables (i.e., common factors) influence the two variables, stock prices may be reciprocally associated with exchange rate dynamics and macroeconomic variables or be influenced by the exchange rate and macroeconomic variables behavior.

The research objectives of this study are to fill the gap in the literature and to provide additional evidence on both the short-run and long-run dynamic relationships between selected macroeconomic variables and both exchange rates and stock prices in the Korean Stock Exchange.

\section{Literature Review}

The fluctuation of stock prices has long intrigued economists, financial analysts, investors as well as academics. A plethora of literature has examined and studied many factors that seem to have an impact on stock prices, most notably macroeconomics variables and monetary policy. Two major influences on stock prices are discussed including macroeconomic variables and external shocks.

\subsection{Stock Prices and Macroeconomic Variables}

Scores of studies conducted to examine the relationship between stock prices and macroeconomic variables are identified here by regions.

Three Largest European Economies. The study of the relationship of stock prices and macroeconomic variables by Peiro (2016) in the three largest European economies, namely, France, Germany and the United Kingdom, found the industrial production index and interest rates affected stock prices in all three countries. In addition, Pier found that the results differed noticeably from the United States, where the only factor affecting US stock prices was the industrial production index (IPI).

The Middle East. Likewise, investigation of stock prices on the Amman Stock Exchange in Jordan with a set of macroeconomic variables discovered a bi-directional long-run relationship between stock prices, credit to private sector, weighted average interest rate on time deposit, as well as, the consumer price index or CPI (Al-Majali \& Al-Assaf, 2014). Furthermore, long-run relationships existed between stock prices and macroeconomic variables such as interest rates, money supply, exchange rates, the industrial production index, gold prices, and the CPI in the Turkish market (Büyükşalvarc \& Abdioğlu, 2010; Alrub, Tursoy, \& Rjoub, 2016).

Emerging Economies. In emerging economies specifically Brazil, Russia, India and China (BRIC), Gay (2016) revealed no significant relationship between stock prices and macroeconomic variables such as exchange rate and oil prices. Yet, Raja and Kalyanasundaram (2010) found that inflation had significant impact on stock prices in India, whereas in Brazil, gross domestic product (GDP), inflation and interest rates showed significant relationship with stock prices. Moreover, a significant relationship existed between stock prices in emerging markets and macroeconomic variables such as money supply, goods prices, real activity and exchange rates while local factors seem to have more weight in affecting the stock prices as compared to global factors (Bilson, Brailsford \& Hooper, 2009).

The Indian Subcontinent. Some literature on the relationship of stock prices and various macroeconomic variables in the Indian market, such as Agrawalla and Tuteja (2008), Sampath (2011), Kumar (2011), Sangmi and Hassan (2013), Kotha and Sahu (2016), and Mangala and Rani (2015) reveals findings that vary depending on the time period and data set. Agrawalla and Tuteja (2008), Sampath (2011), and Kotha and Sahu (2016) used data from the Bombay Stock Exchange (BSE), whereas the rest employed data from the National Stock Exchange of India (NSE). Both Agrawalla and Tuteja (2008) and Sampath (2011) exposed uni-directional causality and significant positive relationship between economic growth (proxied by industrial production index) and stock prices.

According to Kotha and Sahu (2016), there is bidirectional causality between stock prices and exchange rate in the short-run, and significant relationship between stock prices and the wholesale price index, money supply as well as Treasury bill rates in the long-run. However, the study by Kumar (2011), which used stock prices data from the NSE, found no co-integration between the stock prices with macroeconomic variables such as exchange rate, balance of trade (BOT), foreign direct investment (FDI), 
and the industrial production index. Further, no significant causality was found between stock prices and the wholesale price index, which implies that the real sector does not affect the stock market (Kumar, 2011). This was supported by findings by Sangmi and Hassan (2013) that showed no significant relationship between NSE stock prices with the variables examined such as inflation, the industrial production index, money supply, gold prices, and interest rates with the exception of a negative relationship with exchange rates whereby an increase in exchange rate caused lower stock prices. Reinvestigation of the relationship between NSE stock prices and macroeconomic variables (inflation rate, exchange rate, industrial production index, gold price, money supply and short-term interest rate), Mangala and Rani (2015) found short-run causality from exchange rate to stock prices and from stock prices to money supply and inflation rate. Additionally, long-run causality was found from stock prices to short-term interest rate and money supply.

Addressing the relationship between stock prices and macroeconomic variables such as money supply, inflation, exchange rate, and GDP growth rate in Pakistan from 1961 to 2009, Ahmad, Ahmad, Khan and Javaid (2012) showed that only inflation and exchange rate had significant negative impact on stock prices whereas GDP growth rate and money supply showed a weak positive impact and insignificant positive impact, respectively.

North and South Asia. Further study of the relationship between stock prices and macroeconomic variables, such as employment rate, exchange rate, GDP, inflation and money supply in Taiwan from 2003 to 2008 detected that only the exchange rates and GDP had a significant impact on the stock prices (Singh, Mehta, \& Varsha, 2011).

For Southeast Asian countries, Kabir, Bashar and Masih (2014), using the Kuala Lumpur Composite Index (KLCI) data; and Hussin, Muhammad, Abu and Awang (2012), using the Kuala Lumpur Syariah Index (KLSI) data, examined the relationship between stock prices and macroeconomic variables in Malaysia. Both studies displayed a significant relationship between stock prices and exchange rates suggesting that Malaysian listed companies might be dealing with international trade directly or indirectly. Also, the industrial production index and CPI have a significant positive relationship with stock prices whereas money supply and exchange rates are negatively related to stock prices (Hussin et al., 2012). In addition, a significant longrun relationship between stock prices and macroeconomic variables, such as industrial production index, money supply, oil prices and nominal exchange rates were discovered in Thailand for the period of 1992 to 1997 (pre financial crisis). However, for the period of post-financial crisis in Thailand (1997 to 2003), the study found no relationship between stock prices and macroeconomic variables such as industrial production index and oil prices, which might be a result of government intervention and control (Brahmasrene \& Jiranyakul, 2007). A study by Hussainey and Ngoc (2009) on the effects of macroeconomic variables, such as interest rate and industrial production index on Vietnamese stock prices for the period of 2001 to 2008 found that only the industrial production index had positive effect on stock prices.

Finally, a literature review by Bahmani-Oskooee and Saha (2015) concluded that the relationship between stock prices and exchange rate is only short-run, and no longrun relationship is found. The findings from the reviewed literatures were very specific regarding the study period, the countries chosen, as well as other macroeconomic variables selected.

\subsection{Stock Prices and External Shocks}

Studies on the relationship between stock prices and external shocks identify the following results. Stock prices in the Czech Republic, Hungary, Poland and Slovenia were found to be significantly affected by Euro area monetary policy as compared to their own domestic monetary policy implying that financial integration resulted in the sensitivity of stock prices to external shocks (Pirovano, 2012).

The 1997 Asian financial crisis (July 1997 - December 1999) was a period of financial crisis that gripped much of East Asia beginning in July 1997, and raised fears of a worldwide economic meltdown due to financial contagion. In South Korea, the banking sector was burdened with nonperforming loans as its large corporations were funding aggressive expansions. During that time, many businesses ultimately failed to ensure returns and profitability. In the wake of the Asian market downturn, Moody's lowered the credit rating of South Korea from A1 to A3, on 28 November 1997, and downgraded again to B2 on 11 December 1997 (Hahm, 2005; Lim, 2005). The downgrading contributed to a further decline in South Korean shares since stock markets were already bearish in November 1997. First, the South Korean won weakened to more than 1,700 per US dollar from around 800 , but later managed to recover by the end of 1999. Also, its national debt-to-GDP ratio more than doubled (approximately $13 \%$ to $30 \%$ ) as a result of the crisis (Hahm, 2005; Lim, 2005).

\subsection{Hypotheses}

Based on the aforementioned literature, macroeconomic variables and exchange rates are likely related to stock prices. This study includes money supply (M2), industrial production index (IPI), inflation (consumer price index), foreign exchange rates, and short-term interest rate (i.e., certificate of deposit). Accordingly, the following hypotheses are considered: 
H1: There is a long-run equilibrium relationship between stock prices and macroeconomic variables in Korea

H2: Money supply (M2) is related to stock prices in the short-run.

H3: Industrial Production Index (IPI) is related to stock prices in the short-run.

H4: Inflation (CPI) is related to stock prices in the shortrun.

H5: Exchange rate (USD) is related to stock prices in the short-run.

H6: Short-term interest rate (CD) is related to stock prices in the short-run.

H7: External shocks are related to stock price dynamics in the short-run.

\section{Data and Methods}

This section describes the data and outlines the methodology used in the selection of indicators. The sample is restricted to the period for which monthly data are available, which is from January 1986 to October 2016 (370 observations). All of the monthly time series data below are collected and retrieved from the Economic Statistics System database sponsored by the Bank of Korea.

\subsection{Variables and Indicators}

\subsubsection{Endogenous Variables (Macroeconomic Variables)}

Korea Stock Exchange Market Price. The Korea Composite Stock Price Index (KOSPI) is used as a proxy of the Korean stock market prices. This major stock market index tracks the general performance of all common shares listed on the Korean Stock Exchange. The KOSPI index is a capitalization-weighted index of all common shares on the Korean Stock Exchange. The index was developed with a base value of 100 as of January 4, 1980. Monthly average of this index is used in this study.

Money Supply (M2): M2 is a measure of the money supply that includes all elements of M1 as well as "near money." M1 includes cash and checking deposits, while near money refers to savings deposits, money market securities, mutual funds and other time deposits. These assets are less liquid than M1 and not as suitable as exchange mediums, but they can be quickly converted into cash or checking deposits.

Industrial Production Index (IPI): IPI is an economic indicator that measures real output for all facilities located in an economy manufacturing, mining, and electric, and gas utilities. The index is compiled on a monthly basis to bring attention to short- term changes in industrial production. It measures movements in production output and highlights structural developments in the economy. Growth in the production index from month to month is an indicator of growth in the industry.

Consumer Price Index (CPI): CPI is a measure that examines the weighted average of prices of a basket of consumer goods and services, such as transportation, food and medical care. It is calculated by taking price changes for each item in the predetermined basket of goods and averaging them. Changes in the CPI are used to assess price changes associated with the cost of living. CPI is one of the most frequently used statistics for identifying periods of inflation or deflation.

Foreign Exchange Rate (USD): The Korean won per the US dollar (USD) is selected based on the volume of international trade with South Korea,. The time series data is a monthly-adjusted average. In effect, $F X_{-} U S D$ is the logarithm of the nominal exchange rate of Korean won per US dollar.

Certificate of Deposit (CD): A certificate of deposit is a savings certificate with a fixed maturity date, specified fixed interest rate, and can be issued in any denomination aside from the minimum investment requirements, which differ among instruments. A CD restricts access to the funds until the maturity date of the investment. CDs are generally issued by commercial banks. When the $\mathrm{CD}$ matures, the entire amount of principal as well as interest earned is available for withdrawal.

\subsubsection{Exogenous Variable (Global Financial Crises)}

In addition to the 1997 Asian financial crisis (July 1997 - December 1999), the 2007 Global Financial Crisis (August 2007 - December 2009) may also cause a structural break in the trend of stock prices in the Korean stock market. Because the global financial crisis would introduce some changes in the implementation of monetary policy, for example, from monetary targeting to interest rate targeting, this would introduce substantial instability in the system.

An exogenous variable (i.e., global financial crisis) is used to examine the impacts of the 1997 Asian financial crisis and the 2007 global financial crisis on the Korean stock market. However, the dummy here is used as an exogenous variable because it is assumed not to be systematically affected by changes in the endogenous variables of the model (Brahmasrene, Huang, \& Sissoko, 2014). A dummy variable with a value of zero will cause the variable's coefficient to disappear, and a dummy with a value one will cause the coefficient to act as a supplemental intercept in the regression model. Hence, the Asian financial crisis period (July 1997 - December 1999) or the global financial crisis (August 2007 - December 2009) variable equals one if the month falls into one of the crisis period and zero if it falls outside these periods. 


\subsection{Descriptive Statistics of Data}

All these time series data have been collected and retrieved from the Economic Statistics System database sponsored by the Bank of Korea. For all these time series data are reported on a monthly basis and employed for the period from January 1986 to June 2018 (390 observations). Table 1 displays descriptive statistics along with various summary statistics for the time series. Table 2 displays the results of Pearson correlation analysis between the time series.

\subsection{Unit Root Test}

It is well known in the literature that the data-generating process for many economic variables is characterized by stochastic trends that might result in spurious inference if the time series properties are not carefully investigated. A time series is said to be stationary if the mean and autocovariances of the series do not depend on time. Any series that is not stationary is said to be non-stationary (i.e., it has a unit root). The formal method to test the stationarity of a series is the unit root test. There are several well-known tests for this purpose based on individual time series: the augmented Dickey-Fuller (ADF) unit root test (Dickey \& Fuller, 1979, 1981), the Phillips-Perron (PP) unit root test (Phillips \& Perron, 1988), and the Kwiatkowski, Phillips, Schmidt and Shin (KPSS) unit root test (Kwiatkowski, Phillips, Schmidt, \& Shin, 1992), among others.
Table 3 reports the results of unit root tests. All test equations were tested by the method of least squares, including an intercept, but no time trend in the model. Probabilities for all tests assume asymptotic normality. In the ADF and PP tests, an optimal lag in the tests is automatically selected based on Schwarz Info Criterion and the lag length (bandwidth) in the tests is automatically selected based on the Newey-West estimator (Newey \& West, 1994) using the Bartlett kernel function. In ADF and PP tests, probability values for rejection of the null hypothesis of a unit root are employed at the 0.05 level based on MacKinnon (1996) onesided p-values. KPSS tests the null hypothesis: a series has no unit root (stationary), while the alternative hypothesis assumes that the series has a unit root (non-stationary). In KPSS test, the probability values for rejection of the null hypothesis are based on Kwiatkowski, Phillips, Schmidt and Shin (1992) LM statistic p-values.

\section{Results}

A linear combination of two or more non-stationary series may be stationary (Engle \& Granger, 1987). If such a stationary linear combination exists, the non-stationary time series are said to be cointegrated. If these variables are cointegrated, then there exists long-run equilibrium among the variables. In other words, if the variables are cointegrated, there is a long-run relationship, and there exists a force to converge into long-run equilibrium.

Table 1: Descriptive Statistics of KOSPI and Macroeconomic Variables (monthly, 1986-2018)

\begin{tabular}{|l|c|c|c|c|c|}
\hline Variables & Unit & Minimum & Maximum & Mean & Std. Deviation \\
\hline KOSPI & & 157 & 2153 & 1087 & 563 \\
\hline M2 & Billion Won & 43133 & 2391059 & 881630 & 685077 \\
\hline IPI & & 50 & 111 & 111 & 75 \\
\hline CPI & & 34 & 1706 & 1004 & 23 \\
\hline USD & & 666 & 23.10 & 9.07 & 206 \\
\hline CD & $\%$ & 1.34 & 6.40 \\
\hline
\end{tabular}

Table 2: Pearson Correlations ( $\mathrm{N}=390)$

\begin{tabular}{|c|c|c|c|c|c|}
\hline Variables & KOSPI & M2 & IPI & CPI & USD \\
\hline M2 & $.891^{* * *}$ & & & & \\
\hline IPI & $.844^{* * *}$ & $.948^{* * *}$ & & & \\
\hline $\mathrm{CPI}$ & $.840^{* * *}$ & $.968^{* * *}$ & $.978^{\star \star * *}$ & & \\
\hline USD & $.241^{* * *}$ & $.590^{* * *}$ & $.656^{* * *}$ & $.662^{* * *}$ & \\
\hline$C D$ & $-.699^{* * *}$ & $-.866^{* * *}$ & $-.880^{* * *}$ & $-.923^{* * *}$ & $-.664^{* *+}$ \\
\hline
\end{tabular}

Note: Correlation is significant at the 0.01 level ${ }^{* * *}, p$-value $<0.01,2$-tailed). 
Table 3: Results of Unit Root Tests

\begin{tabular}{|l|c|c|c|c|c|c|}
\hline Variables & ADF(0) & ADF(1) & PP(0) & PP(1) & KPSS(0) & KPSS(1) \\
\hline KOSPI & -2.057 & $-13.496^{* * *}$ & -2.170 & $-13.447^{* * *}$ & $1.796^{* * *}$ & 0.161 \\
\hline M2 & -1.878 & $-9.891^{* * *}$ & -1.891 & $-9.985^{* * *}$ & $2.291^{* * *}$ & 0.342 \\
\hline IPI & -1.372 & $-10.703^{* * *}$ & -1.375 & $-10.498^{* * *}$ & $2.320^{* * *}$ & 0.217 \\
\hline CPI & -2.170 & $-12.497^{* * *}$ & -2.259 & $-13.247^{* * *}$ & $2.323^{* * *}$ & 0.373 \\
\hline USD & -1.613 & $-13.563^{* * *}$ & -1.702 & $-11.053^{* * *}$ & $1.369^{* * *}$ & 0.056 \\
\hline CD & -0.357 & $-8.667^{* * *}$ & -0.320 & $-11.887^{* * *}$ & $2.291^{* * *}$ & 0.062 \\
\hline
\end{tabular}

Note: The numeric values in cells are t-statistic. Probability values for rejection of the null hypothesis are employed at the $5 \%$ significant level $\left({ }^{* *}, \mathrm{p}\right.$-value $<0.05$ and $^{* * *}, \mathrm{p}$-value $\left.<0.01\right)$.

Table 4: Results of Johansen Cointegration Test

\begin{tabular}{|c|c|c|}
\hline Number of cointegration $(r)$ & Trace statistic & Maximum eigenvalue statistic \\
\hline$r=0$ & $148.607(95.753)^{* * *}$ & $64.549(40.077)^{* * *}$ \\
\hline$r \leq 1$ & $84.058(69.818)^{* * *}$ & $32.071(33.876)$ \\
\hline$r \leq 2$ & $51.986(47.856)^{* *}$ & $21.193(27.584)$ \\
\hline$r \leq 3$ & $30.793(29.797)$ & $18.590(21.131)$ \\
\hline$r \leq 4$ & $12.202(15.494)$ & $8.672(14.264)$ \\
\hline$r \leq 5$ & $1.072(2.652)$ & $1.072(2.652)$ \\
\hline
\end{tabular}

Note: Regression model: LOG_KOSPI = LOG_M2 LOG_IPI LOG_CPI LOG_CD LOG_USD

The values in parenthesis are critical values at the 0.05 level.

Cointegrating equations are significant at the 0.05 level $\left({ }^{* *}, p\right.$-value $<0.05$ and ${ }^{* * *}, p$-value $\left.<0.01\right)$.

\subsection{Cointegration Test}

There are two test methods to identify whether there is a long-run relationship among variables: the Engle-Granger single equation test method (Engle \& Granger, 1987) and the Johansen conintegration test (Johansen, 1988). Cheung and Lai (1993) report that the Johansen approach is more efficient than the Engle-Granger single equation test method because the maximum likelihood procedure has useful large and finite sample properties. The Johansen cointegration test models each variable as a function of all the lagged endogenous variables in the system. In addition, the procedure uses two ratio tests: a trace test and a maximum eigenvalue test, to test the number of cointegration relationships. Both tests can be used to determine the number of cointegrating vectors present, although they do not always indicate the same number of cointegrating vectors.

Table 4 presents the results of the Johansen cointegration test. The test equation was tested by the method of least squares. The regression model allows for a linear deterministic trend in the data and includes an intercept, but no trend in vector autoregressive models. Lags interval in first differences is 1 to 4 . For the two likelihood ratio test statistics, the probability value for rejection of the null hypothesis of no cointegration is based on the MacKinnon, Haug and Michelis (1999) p-values. The null hypothesis of no cointegration is rejected at the $5 \%$ significance level. Both the trace and the maximum eigenvalue tests indicate that at least one cointegrating equation exist at the 0.01 level. Therefore, the null hypothesis of no cointegration can be rejected at the 0.01 level. The results of the Johansen cointegration test in Table 4 support hypothesis 1 that there is a long-run equilibrium relationship between macroeconomic variables and stock prices in Korea.

\subsection{Vector Error Correction Estimates}

Considering the results of the Johansen cointegration test in Table 4, it is evident that there is a long-run equilibrium relationship between stock prices and macroeconomic variables in Korea. In this case, an unrestricted vector autoregressive model (VAR) would not be an effective option for testing short-run dynamics. Engle and Granger (1987) noted that, if two or more variables are cointegrated, there is always a corresponding error correction representation in which the short-run dynamics of the variables in the system are influenced by the deviation from equilibrium. The cointegrated variables must have an error correction 
representation in which an error correction term is incorporated into the model (Toda \& Phillips, 1993, 1994). In this case, a vector error correction model is formulated to reintroduce the information lost in the differencing process, thereby allowing for long-run equilibrium as well as shortrun dynamics. The vector error correction model (VECM) implies that changes in one variable are a function of the level of disequilibrium in the cointegrating relationship (captured by the error correction term), as well as changes in other explanatory variables. Thus, the vector error correction model is useful for detecting the long-run and short-run elasticity when the variables are cointegrated.

The VECM is a technique that facilitates the capture of both the dynamic and interdependent relationships of the particular variables and is a special type of restricted VAR, which can correct a disequilibrium that may shock the whole system. The VECM can distinguish between the short-run and long-run elasticity because it can capture both the shortrun and the long-run dynamics. The long-run dynamics are determined by the error correction term. The long-run elasticity is implied by the significance of the t-test of the lagged error correction terms. The multivariate vector error correction model provides t-statistics that are used to interpret the statistical significance of coefficients of the regressors.

Statistical inference is sensitive to parameter instability, serial correlation in residuals and residual skewness. The results of VECM estimates, model diagnostic tests and residual diagnostic tests indicate that there are considerably fewer outliers and the fluctuation bands are smaller. Skewness of the series is not significantly different from a normal distribution. Histogram normality using the JarqueBera test (null hypothesis: residuals are multivariate normal) is rejected. Breusch-Godfrey serial correlation Lagrange multiplier or LM test (null hypothesis: no serial correlation at lag order 2) is rejected. Heteroskedasticity test (null hypothesis: no autoregressive conditional heteroskedasticity or ARCH effect at lag order 1) is also rejected. Thus, this model yields acceptable results.

Table 5 reports the results of VECM estimates. The coefficient of ECT(t-1) is significant with a negative sign at the 0.01 level, which indicates that the lagged structure of ECT(t-1) is unstable (see Figure 1). The result confirms that a negative dynamic relationship from macroeconomic variables to the Korean stock market in the long-run is observed.

Table 5 reports the results of VECM estimates. In testing hypotheses 2, 3 and 4, that money supply (M2), industry production index (IPI) and inflation (CPI) are related to stock prices in the short-run, Table 5 shows that M2, IPI and CPI are insignificant at the 0.05 level.

With respect to hypothesis 5 , that an exchange rate is related to stock prices in the short-run, the coefficient of the exchange rate is significant with a positive sign at the 0.05 level. The result indicates the nominal exchange rate of the Korean won per the US dollar is positively related to stock prices in the short-run.

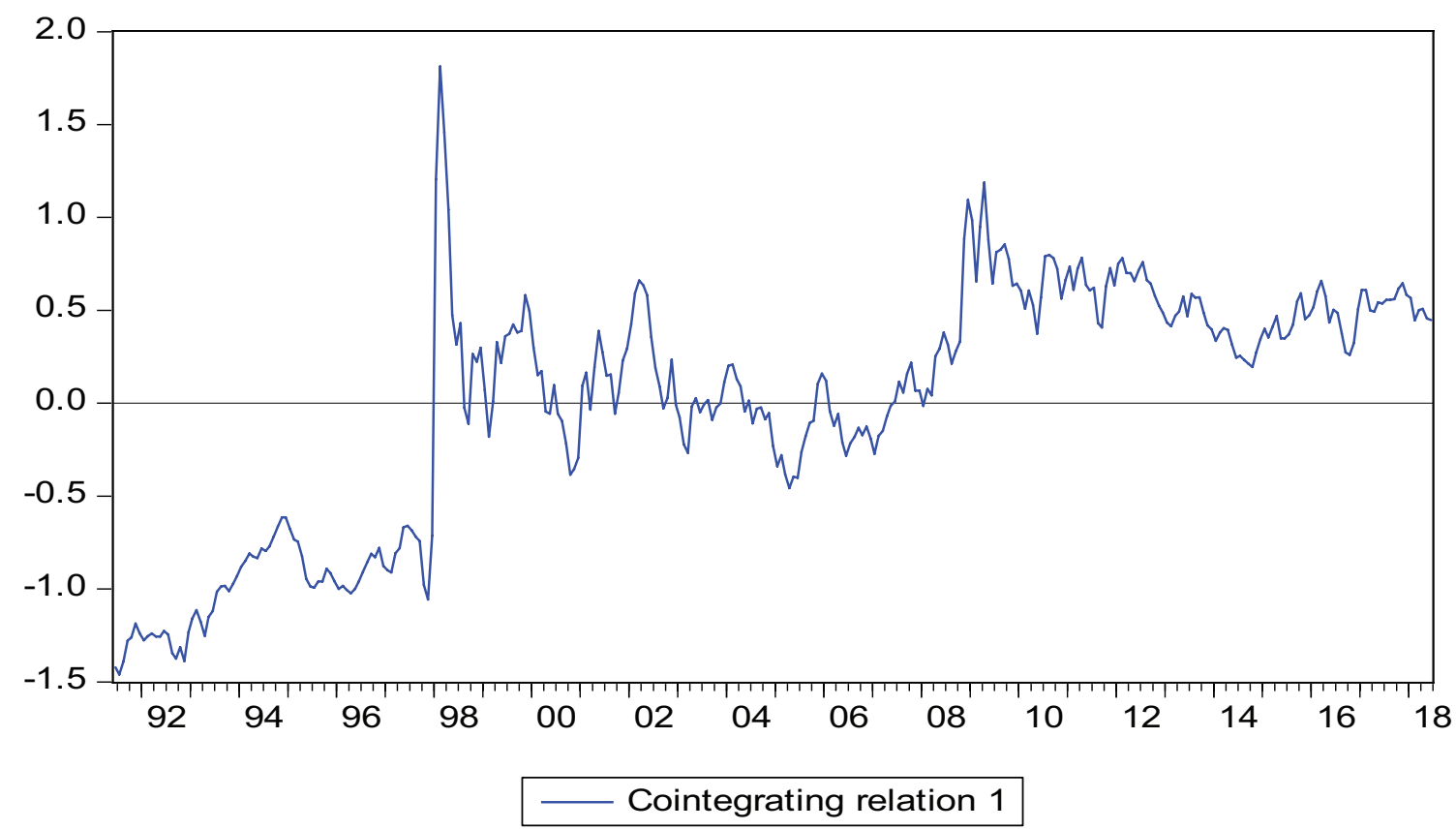

Figure 1: Cointegration Graph of the Cointegrating Equation 
Table 5: Results of Vector Error Correction (VEC) Estimates

\begin{tabular}{|c|c|c|c|}
\hline & $\begin{array}{l}\text { Endogenous variables: } \\
\text { Lag order in ( ) }\end{array}$ & $\begin{array}{c}\text { VEC model } 1 \\
\text { including Exogenous crisis }\end{array}$ & $\begin{array}{c}\text { VEC model } 2 \\
\text { excluding Exogenous crisis }\end{array}$ \\
\hline & $\begin{array}{l}\text { Dependent variable: } \\
\Delta \operatorname{KOSPI}(\mathrm{t})\end{array}$ & $\begin{array}{l}\text { Coefficient } \\
\text { t-statistics in [ ] }\end{array}$ & $\begin{array}{c}\text { Coefficient } \\
\text { t-statistics in [ ] }\end{array}$ \\
\hline $\begin{array}{l}\text { Long-run } \\
\text { dynamics }^{1}\end{array}$ & $E C T_{t-1}$ : error correction term & $-0.049[-2.880]^{\star \star \star}$ & $-0.039[-2.678]^{\star * \star}$ \\
\hline \multirow{13}{*}{$\begin{array}{l}\text { Short-run } \\
\text { dynamics }^{2}\end{array}$} & $\Delta \mathrm{KOSPI}(\mathrm{t}-1)$ & $0.125[2.104]^{* *}$ & $0.115[1.952]^{* *}$ \\
\hline & $\Delta \mathrm{KOSPI}(\mathrm{t}-2)$ & $0.032[0.534]$ & $0.025[0.414]$ \\
\hline & $\Delta \mathrm{M} 2(\mathrm{t}-1)$ & $0.477[0.573]$ & 0.493 [0.592] \\
\hline & $\Delta \mathrm{M} 2(\mathrm{t}-2)$ & $-1.366[-1.680]$ & $-1.327[-1.635]$ \\
\hline & $\Delta \mathrm{IPI}(\mathrm{t}-1)$ & $-0.669[-0.843]$ & $-0.690[-0.871]$ \\
\hline & $\Delta \mathrm{IPI}(\mathrm{t}-2)$ & $-0.850[-1.056]$ & $-0.862[-1.073]$ \\
\hline & $\Delta \mathrm{CPI}(\mathrm{t}-1)$ & $0.949[0.706]$ & $0.969[0.722]$ \\
\hline & $\Delta \mathrm{CPI}(\mathrm{t}-2)$ & $1.594[1.179]$ & 1.674 [1.242] \\
\hline & $\Delta \mathrm{CD}(\mathrm{t}-1)$ & $-0.157[-1.928]^{* *}$ & $-0.163[-2.023]^{* *}$ \\
\hline & $\Delta \mathrm{CD}(\mathrm{t}-2)$ & $0.004[0.058]$ & $0.001[0.005]$ \\
\hline & $\Delta \mathrm{USD}(\mathrm{t}-1)$ & $0.397[2.187]^{\star *}$ & $0.405[2.227]^{* *}$ \\
\hline & $\Delta \mathrm{USD}(\mathrm{t}-2)$ & $-0.198[-1.069]$ & $-0.211[-1.140]$ \\
\hline & Constant & $0.001[0.126]$ & 0.004 [0.459] \\
\hline $\begin{array}{l}\text { Exogenous } \\
\text { variable }\end{array}$ & Financial crisis & 0.010 [1.099] & \\
\hline \multirow{3}{*}{$\begin{array}{l}\text { Model } \\
\text { diagnostic tests }\end{array}$} & R-squared & $=0.134$ & $=0.131$ \\
\hline & Adjusted R-squared & $=0.092$ & $=0.092$ \\
\hline & F-statistic & $=3.209^{* * *}$ & $=3.358^{* * *}$ \\
\hline
\end{tabular}

The probability value for rejection of the null hypothesis is employed at the 0.05 level $\left({ }^{* *} p<0.05\right.$ and $\left.{ }^{* * *}, p<0.01\right)$.

${ }^{1}$ Long-run dynamics equation: D(LOG_KOSPI) $=\mathrm{C}(1)^{*}($ LOG_KOSPI(-1) - 7.27539063048*LOG_M2(-1) - 17.3224885762*LOG_IPI(-1)

$+37.8907144192 *$ LOG_CPI(-1) + 3.06259223616*LOG_CD (-1) + 1.33398986317*LOG_USD $(-1)-8.61898589147)$

${ }^{2}$ Short-run dynamics equation: $\mathrm{D}($ LOG_KOSPI $)=\mathrm{C}(2)^{*} \mathrm{D}($ LOG_KOSPI $(-1))+\mathrm{C}(3)^{*} \mathrm{D}($ LOG_KOSPI $(-2))+\mathrm{C}(4)^{*} \mathrm{D}\left(\mathrm{LOG} \_\mathrm{M} 2(-1)\right)+$

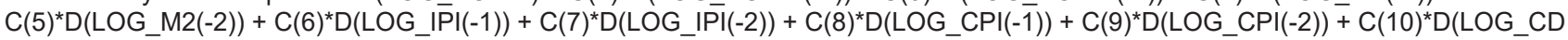

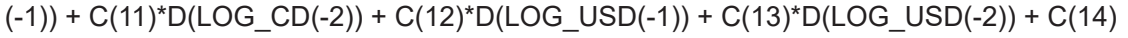

According to hypothesis 6, that short-term interest rate (CD) is related to stock prices in the short-run, the empirical evidence indicates the short-term interest rate is significant at the 0.05 level, which indicates that the short-term interest rate is negatively related to stock prices.

Finally, hypothesis 7 postulates that global financial crises are related to stock price dynamics in in the long-run and the short-run. The coefficient of the global financial crises is insignificant, that is, the changes of stock prices in the long-run and the short-run in Korea are determined largely by their own dynamics in the model. The result suggests only that the global financial crises do not cause instability in the cointegrating vector nor affect significant changes in the endogenous variables in the model.

\subsection{Impulse Responses}

In addition to the findings corresponding to the above hypotheses, theimpulse responses and variance decomposition may be noteworthy in their impact. A shock to the $j$-th variable not only directly affects that variable but is also transmitted to all of the other endogenous variables through the dynamic (lag) structure of the vector autoregressive. The effects of the shocks on the endogenous variables can be assessed by estimating impulse responses and variance decomposition functions. An impulse response function traces the effect of a one-time shock to one of the innovations on current and future values of the endogenous variables. Since innovations are usually correlated, it may be viewed as having a common 
component that cannot be associated with a specific variable. In order to interpret the impulses, it is common to apply a transformation to the innovations that cause them to become uncorrelated. The Cholesky transforming method uses the inverse of the Cholesky factor of the residual covariance matrix to orthogonalize the impulses. This method imposes an ordering of the variables in the vector autoregressive and attributes all of the effect of any common component to the variable that comes first in the vector autoregressive system. For stationary vector autoregressive models, the impulse responses should die out to zero and the accumulated responses should be asymptote to some constant.

Figure 2 presents the results of the impulse responses of stock prices to Cholesky one standard deviation innovations of only three significant endogenous variables: stock price (KOSPI), short-term interest rates (CD) and exchange rates (USD).

The impulse response of stock prices itself to each shock shows a positive impact throughout with an increase in the first four months, and stabilizing afterwards. But, when the response reaches the upper turning point, it gradually declines. The response of stock prices to KOSPI innovations decreases in subsequent periods and leveling off after twenty-four months eventually.

The impulse response of stock prices to short-term interest rates (CD) shock shows a negative impact throughout with an increase in the first four months, and stabilizing afterwards. The response of stock prices to CD innovations decreases in subsequent periods and all through, continues a negative impact while gradually declines.

The response of stock prices to exchange rates (USD) shock shows a positive impact in the first four months, and then gradually declines and then turns out a negative impact in subsequent periods. The response of stock prices to USD innovations decreases in subsequent periods and leveling off after eighteen months eventually.

\section{Discussion and Policy Implication}

This research contributes to the existing literature in three main aspects. First, this research uncovers the fact that there exists a long-run equilibrium relationship between macroeconomic variables and stock prices in Korea. Second, the paper empirically explores the short-term dynamic relationships between selected macroeconomic variables and stock prices in Korea as follows:

For stock prices (KOSPI) itself, the lagged period of stock prices has positive influence on current period while the two-lagged period of M2, IPI and CPI shows no significant influence on current period. This may prompt investors not to base their expectations of future results on past performance. The likelihood of various stock price outcomes is hypothetical in nature, and everybody should realize about the ups and downs of stock market.

Interest rates (CD) are negatively related to stock prices in the short-run with a significant coefficient of -0.163 . This means that the system corrects its previous period disequilibrium 0.16 times reflecting a sizable speed of adjustment to reach equilibrium steady state position.

The coefficient value of exchange rates, i.e., Korean won per USD is 0.405 . This short-run coefficient also represents the short-run equilibrium. It implies the rate at which the previous period disequilibrium of the system is being corrected. Thus, the system corrects its previous period disequilibrium at a speed of 40.5 percent between the USD exchange rate and KOSPI. This confirms findings by Kabir, Bashar and Masih (2014) and Hussin, Muhammad, Abu and Awang (2012) employing data from Malaysia. During period under study, a depreciation of the Korean won makes Korean exports more competitive but raises the cost of importing goods into Korea. This results in a decline in imports and an increase in exports. Hence, domestic firms will benefit from increased sales. An increase in exports raises profits

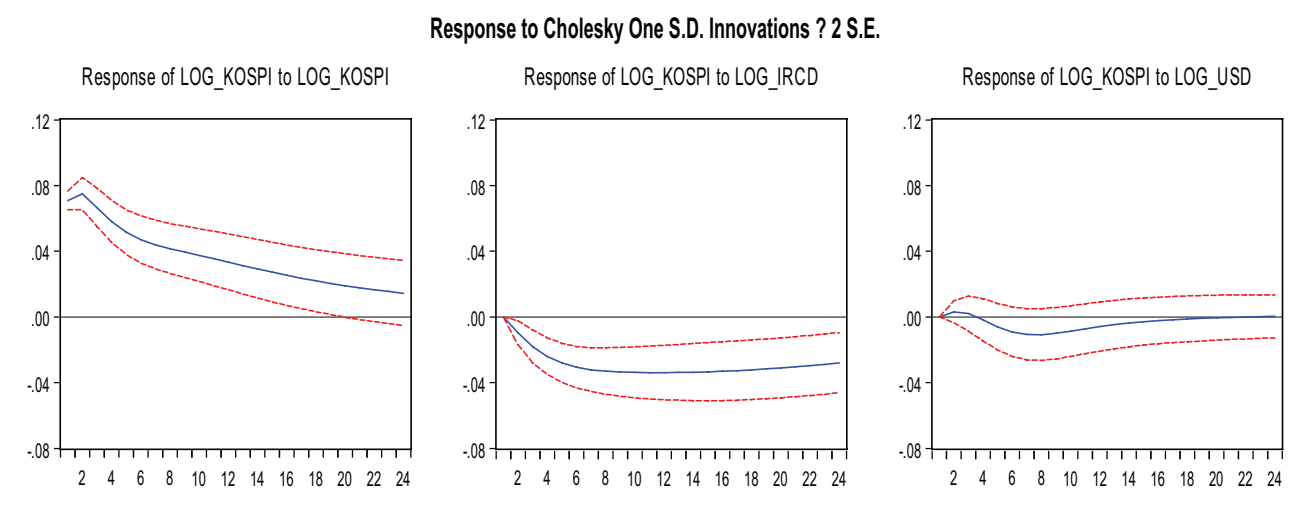

Note: The confidence bands are computed using the $95 \%$ confidence intervals. The dotted red lines in graphs display standard error bands. The graphs are displayed in 24 periods with two lags.

Figure 2: Impulse Response of KOSPI to Macroeconomic Variables 
and the firms' value along with stock prices. The increased demand for stocks drives prices up further when investors shift their portfolio from bonds to stocks to profit from rising stock prices.

Finally, there is no compelling evidence that the global financial crises impact on the stock price dynamics in the Korean stock market. In light of these findings, financial managers can enhance their understanding of the short-run movements of interest rates, exchange rates, and stock price dynamics. A better understanding of these short-run and long-run movements enables financial managers to make better informed investment and financial decisions.

\section{Conclusions}

Recommendations can be drawn from the findings presented in this paper. From a long-term perspective, policymakers should consider selected macroeconomics such as money supply, industrial production index, inflation, exchange rates, and interest rates as policy tools aiming at the Korean stock market since the results show evidence of a long-run equilibrium relationship among them. However, from a short-term perspective, policymakers may consider the US dollar exchange rates and short-term interest rates (CD) as policy tools to manage and control the Korean stock market since these two variables, to some extent, may cause a positive/negative effect on stock prices in Korea. This policy should be effective in the short-run then be evaluated in the future.

On the contrary, the results acknowledge that money supply, industrial production index and inflation rates exhibit no relationship on stock prices in Korea. It would appear that this independent behavior of the stock market from these variables could be a state of the market liberalization process for its economy to heal and propel itself toward long-run stability and a better future of the Korean stock market. Therefore, policymakers and investors should devote more time and effort acquiring, not only the information on changes in monetary policy and temporary external shocks in the short-run, but also the knowledge and information about the market itself.

Further research may be directed at some of the above issues. The empirical model may be estimated with alternative economic and financial factors or markets. Studies encompassing different economies should be conducted where data is available. Such research should contribute toward improving our understanding of the market mechanism and responses of each market to the frequently occurring phenomena of economic and financial crisis, whether regional or global.

\section{References}

Agrawalla, R. K., \& Tuteja, S. K. (2008). Share Prices and Macroeconomic Variables in India: An Approach to Investigate the Relationship Between Stock Markets and Economic Growth. Journal of Management Research, 8(3), 136-146.

Ahmad, Z., Ahmad, Z., Khan, M. S., \& Javaid, U. (2012). Capturing the stock price movements at Karachi Stock exchange: Are macroeconomic variables relevant? African Journal of Business Management, 6(8), 3026-3034.

Al-Majali, A. A., \& Al-Assaf, G. I. (2014). Long-Run And Short-Run Relationship Between Stock Market Index And Main Macroeconomic Variables Performance In Jordan. European Scientific Journal, 10(10), 156-171. Retrieved May 10, 2019 from http://eujournal.org/index.php/esj/article/ viewFile/3129/2927

Alrub, A. A., Tursoy, T., \& Rjoub, H. (2016). Exploring the Longrun and Short-run Relationship between Macroeconomic Variables and Stock Prices during the Restructuring Period: Does it Matter in Turkish Market? Journal of Financial Studies \& Research, 2016, 1-11.

Bahmani-Oskooee, M., \& Saha, S. (2015). On the relation between stock prices and exchange rates: a review article. Journal of Economic Studies, 42(4), 707-732.

Basistha, A., \& Kurov, A. (2008). Macroeconomic Cycles and the Stock Market's Reaction to Monetary Policy. Journal of Banking \& Finance, 32, 2606-2616.

Bilson, C. M., Brailsford, T. J., \& Hooper, V. J. (2009). Selecting Macroeconomic Variables as Expanatory Factors of Emerging Stock Market Returns. Pacific-Basin Finance Journal, 9, 401-426.

Bjornland, H. C., \& Leitemo, K. (2009). Identifiying the Interdependence between the US Monetary Policy and the Stock Market. Journal of Monetary Economics, 56, 275-282.

Brahmasrene, T., \& Jiranyakul, K. (2007). Cointegration and Causality between Stock Index and Macroeconomic Variables in an Emerging Market. Academy of Accounting and Financial Studies Journal, 11(3), 17-30.

Brahmasrene, T., Huang, J-C. \& Sissoko, Y. (2014). Crude oil prices and exchange rates: Causality, variance decomposition and impulse response. Energy Economics, 44, 407-412.

Branson, W., Halttunen, H., \& Masson, P. (1977). Exchange rate in the short run: the dollar Deutsche mark rate. European Economic Review, 10, 303-324.

Büyükşalvarci, A., \& Abdioğlu, H. (2010). The Causal Relationship between Stock Prices and Macroeconomic Variables: A Case Study for Turkey. International Journal of Economic Perspectives, 4(4), 601-610.

Cheung, Y. W., \& Lai, K. S. (1993). Finite-sample sizes of Johansen's likelihood ratio tests for cointegration. Oxford Bulletin of Economics and Statistics, 55, 313-328. 
Dickey, D. A., \& Fuller, W. A. (1979). Distribution of the estimators for autoregressive time series with a unit root. Journal of the American Statistical Association, 74, 427-431.

Dickey, D. A., \& Fuller, W. A. (1981). Likelihood ratio statistics for autoregressive time series with a unit root. Econometrica, 49, 1057-1071.

Dornbusch, R., \& Fisher, S. (1980). Exchange rates and the current account. American Economic Review, 70(5), 960-971.

Engle, R. F., \& Granger, C. W. J. (1987). Cointegration and error correction: Representation, estimation and testing. Econometrica, 55, 251-276.

Gay, R. D. (2016). Effect Of Macroeconomic Variables On Stock Market Returns For Four Emerging Economies: Brazil, Russia, India, And China. International Business \& Economics Research Journal, 15(3), 119-126.

Granger, C. W. J. (1988). Some recent developments in a concept of causality. Journal of Econometrics, 39, 199-211.

Hahm, J. H. (2005). The Resurgence of Banking Institutions in Post-crisis Korea. Journal of Contemporary Asia, 35(3), 386403. https://doi.org/10.1080/00472330580000221

Hussainey, K., \& Ngoc, L. K. (2009). The impact of macroeconomic indicators on Vietnamese stock prices. The Journal of Risk Finance, 10(4), 321-332.

Hussin, M. Y. M., Muhammad, F., Abu, M. F., \& Awang, S. A. (2012). Macroeconomic Variables and Malaysian Islamic Stock Market: A Time Series Analysis. Journal of Business Studies Quarterly, 3(4), 1-13.

Ioannidis, C., \& Kontonikas, A. (2008). The impact of monetary policy on stock prices. Journal of Policy Modeling, 30, 33-53.

Jansen, D. W., \& Tsai, C.-L. (2010). Monetary Policy and Stock Returns: Financing Constraints and Asymmetries in Bull and Bear Markets. Journal of Empirical Finance, 17, 981-990.

Johansen, S. (1988). Statistical analysis of cointegration vectors. Journal of Economic Dynamics and Control, 12, 231-254.

Kabir, S. H., Bashar, O. K., \& Masih, A. M. (2014). Is Domestic Stock Price Cointegrated With Exchange Rate And Foreign Stock Price? Evidence From Malaysia. The Journal of Developing Areas, 48(3), 285-302.

Kim, H., Kim, J., Lee, J., \& Ryu, D. (2014). The impact of monetary policy on banking and finance stock prices in China. Applied Economics Letters, 21(18), 1257-1261.

Kotha, K. K., \& Sahu, B. (2016). Macroeconomic Factors and the Indian Stock Market: Exploring Long and Short Run Relationships. International Journal of Economics and Financial Issues, 6(3), 1081-1091.

Kumar, A. (2011). An Empirical Analysis of Causal Relationship Between Stock Market And Macroeconomic Variables In India. International Journal of Computer Science \& Management Studies, 11(1), 8-14.
Kwiatkowski, D., Phillips, P. C. B., Schmidt, P., \& Shin, Y. (1992). Testing the null hypothesis of stationary against the alternative of a unit root. Journal of Econometrics, 54, 159-178.

Laeven, L., \& Tong, H. (2012). US Monetary Shocks and Global Stock Prices. Journal of Finanantial Intermediation, 21, 530-547.

Lee, J. W., \& Brahmasrene, T. (2018). An exploration of dynamical relationships between macroeconomic variables and stock prices in Korea. Journal of Asian Finance, Economics and Business, 5(3), 7-17. http://doi.org/10.13106/jafeb.2018.vol5.no3.7

Li, J. (2015). The asymmetric effects of investor sentiment and monetary policy on stock prices. Applied Economics, 47(24), 2514-2522.

Li, Y. D., Iscan, T. B., \& Xu, K. (2010). The Impact of Monetary Policy Shocks and Stock Prices: Evidence from Canada and the Unites States. Journal of International Money and Finance, 29, 876-896.

Lim, S. H. (2005). Foreign Capital Entry in the Domestic Banking Market of Korea: Bitter Medicine or Poison. Korean Political Science Review, 39(4), 189-209. (In Korean).

MacKinnon, J. G. (1996). Numerical distribution functions for unit root and cointegration tests. Journal of Applied Econometrics, $11,601-618$.

Mackinnon, J. G., Haug, A. A., \& Michelis, L. (1999). Numerical distribution functions of likelihood ratio tests for cointegration. Journal of Applied Econometrics, 14, 563-577.

Mangala, D., \& Rani, A. (2015). Revisiting the Dynamic Relationship between Macroeconomic Fundamentals and Stock Prices: An Evidence from Indian Stock Market. International Journal of Financial Management, 5(3), 53-63.

Newey, W., \& West, K. (1994). Automatic lag selection in covariance matrix estimation. Review of Economic Studies, 61, 631-653.

Peiro, A. (2016). Stock Prices and Marcoeconomic Factors: Some European Evidence. International Review of Economics and Finance, 41, 287-294.

Phillips, P. C. B., \& Perron, P. (1988). Testing for a unit root in time series regression. Biometrica, 75(2), 335-346.

Pirovano, M. (2012). Monetary Policy and Stock Prices in Small Open Economies: Empirical Evidence for the new EU Member States. Economic Systems, 36, 372-390.

Raja, J., \& Kalyanasundaram, M. (2010). A Study On The Relationship Between Stock Market Index And Economic Variables Among Emerging Economies. The Journal Contemporary Management Research, 4(2), 1-7.

Sampath, T. (2011). Macroeconomic Variables and Stock Prices in India: An Empirical Analysis. The IUP Journal of Monetary Economics, 9(4), 43-55.

Sangmi, M.-M., \& Hassan, M. M. (2013). Macroeconomic Variables on Stock Market Interactions: The Indian Experience. IOSR Journal of Business and Management, 11(3), 15-28. 
Singh, T., Mehta, S., \& Varsha, M. S. (2011). Macroeconomic factors and stock returns: Evidence from Taiwan. Journal of Economics and International Finance, 2(4), 217-227.

Tang, Y., Luo, Y., Xiong, J., Zhao, F., \& Zhang, Y.-C. (2013). Impact of monetary policy changes on the Chinese monetary and stock markets. Physica A, 392, 4435-4449.

Toda, H. Y., \& Phillips, P. C. B. (1993). Vector autoregressions and causality. Econometrica, 61(6), 1367-1393.

Toda, H. Y., \& Phillips, P. C. B. (1994). Vector autoregression and causality: A theoretical overview and simulation study, Econometric Reviews, 13(2), 259-285.
Vithessonthi, C., \& Techarongrojwong, Y. (2012). The Impact of Monetary Policy Decision on Stock Returns: Evidence from Thailand. Journal of International Financial Markets, Institutions and Money, 22, 487-507.

Zare, R., Azali, M., \& Habibullah, M. S. (2013). Monetary Policy and Stock Market Volatility in the ASEAN5: Asymmetries over Bull and Bear Markets. Procedia Economics and Finance, 7, 18-27.

Zhao, H. (2010). Dynamic relationship between exchange rate and stock price: Evidence from China. Research in International Business and Finance, 24(2), 103-112. 